\title{
Front Matter: Volume 6474
}

, "Front Matter: Volume 6474," Proc. SPIE 6474, Zinc Oxide Materials and Devices II, 647401 (13 March 2007); doi: 10.1117/12.728530

SPIE Event: Integrated Optoelectronic Devices 2007, 2007, San Jose, California, SPIE. United States 


\title{
PROCEEDINGS OF SPIE
}

\section{Zinc Oxide Materials and Devices II}

\author{
Ferechteh Hosseini Teherani \\ Cole W. Litton \\ Editors
}

21-24 January 2007

San Jose, California, USA

Sponsored and Published by

SPIE- The International Society for Optical Engineering

Volume 6474

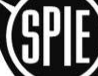

The International Society for Optical Engineering

Proceedings of SPIE-The International Society for Optical Engineering, 9780819465870, v. 6474

SPIE is an international technical society dedicated to advancing engineering and scientific applications of optical, photonic, imaging, electronic, and optoelectronic technologies. 
The papers included in this volume were part of the technical conference cited on the cover and title page. Papers were selected and subject to review by the editors and conference program committee. Some conference presentations may not be available for publication. The papers published in these proceedings reflect the work and thoughts of the authors and are published herein as submitted. The publisher is not responsible for the validity of the information or for any outcomes resulting from reliance thereon.

Please use the following format to cite material from this book:

Author(s), "Title of Paper," in Zinc Oxide Materials and Devices II, edited by Ferechteh Hosseini Teherani, Cole W. Litton, Proceedings of SPIE Vol. 6474 (SPIE, Bellingham, WA, 2007) Article CID Number.

ISSN 0277-786X

ISBN 9780819465870

Published by

SPIE-The International Society for Optical Engineering

P.O. Box 10, Bellingham, Washington 98227-0010 USA

Telephone 1 360/676-3290 (Pacific Time) · Fax 1 360/647-1445

http://www.spie.org

Copyright (c) 2007, The Society of Photo-Optical Instrumentation Engineers

Copying of material in this book for internal or personal use, or for the internal or personal use of specific clients, beyond the fair use provisions granted by the U.S. Copyright Law is authorized by SPIE subject to payment of copying fees. The Transactional Reporting Service base fee for this volume is $\$ 18.00$ per article (or portion thereof), which should be paid directly to the Copyright Clearance Center (CCC), 222 Rosewood Drive, Danvers, MA 01923. Payment may also be made electronically through CCC Online at http://www.copyright.com. Other copying for republication, resale, advertising or promotion, or any form of systematic or multiple reproduction of any material in this book is prohibited except with permission in writing from the publisher. The CCC fee code is 0277$786 \times / 07 / \$ 18.00$.

Printed in the United States of America. 


\section{Contents}

ix Conference Committee

SESSION 1 OPTICAL PROPERTIES

647402 New developments in ZnO materials and devices (Invited Paper) [6474-01]

D. C. Look, Wright State Univ. (USA) and Air Force Research Lab. (USA)

647403 Analysis of localization dynamics of excitons in ZnO-related quantum wells by Monte-Carlo simulation (Invited Paper) [6474-02]

T. Makino, Univ. of Hyogo (Japan)

\section{SESSION 2 ZnO DOPING}

647406 Metalorganic vapor phase epitaxy of ZnO: toward p-type conductivity (Invited Paper) [6474-04]

S. Heinze, A. Dadgar, F. Bertram, A. Krtschil, J. Bläsing, H. Witte, S. Tiefenau, T. Hempel,

A. Diez, J. Christen, A. Krost, Otto-von-Guericke-Univ. Magdeburg (Germany)

647409 Characterization of Ag doped p-type ZnO films (Invited Paper) [6474-07]

G. H. Kim, B. D. Ahn, D. L. Kim, K. H. Jung, S. Y. Lee, Yonsei Univ. (South Korea)

\section{SESSION 3 THIN FILM EPITAXY AND INTERFACES}

64740E Current-transport mechanisms of isotype $\mathrm{n}-\mathrm{ZnO} / \mathrm{n}$-GaN heterostructures (Invited Paper) [6474-12]

Ya. I. Alivov, X. Bo, Q. Fan, S. Akarca-Biyikli, Virginia Commonwealth Univ. (USA);

D. Johnstone, SEMETROL (USA); O. Lopatiuk, L. Chernyak, Univ. of Central Florida (USA);

C. W. Litton, Air Force Research Lab. (USA); H. Morkoç, Virginia Commonwealth Univ. (USA)

Pagination: Proceedings of SPIE follow an e-First publication model, with papers published first online and then in print and on CD-ROM. Papers are published as they are submitted and meet publication criteria. A unique, consistent, permanent citation identifier (CID) number is assigned to each article at the time of the first publication. Utilization of CIDs allows articles to be fully citable as soon they are published online, and connects the same identifier to all online, print, and electronic versions of the publication.

SPIE uses a six-digit CID article numbering system in which:

- The first four digits correspond to the SPIE volume number.

- The last two digits indicate publication order within the volume using a Base 36 numbering system employing both numerals and letters. These two-number sets start with 00, 01, 02, 03, 04, 05, 06, 07, 08, 09, 0A, OB ... 0Z, followed by 10-1Z, 20-2Z, etc.

The CID number appears on each page of the manuscript. The complete citation is used on the first page, and an abbreviated version on subsequent pages. 
64740F Electrical characteristics of $\mathrm{n}-\mathrm{ZnO} / \mathrm{n}-6 \mathrm{H}-\mathrm{SiC}$ heterostructures grown by rf-sputtering [6474-64]

Ya. I. Alivov, B. Xiao, Q. Fan, Virginia Commonwealth Univ. (USA); D. Johnstone, SEMETROL

(USA); C. W. Litton, Air Force Research Lab. (USA); H. Morkoç, Virginia Commonwealth Univ. (USA)

\section{SESSION 4 THIN FILM HETEROSTRUCTURES}

$64740 \mathrm{H}$ Thin film growth of ZnO and its relation to substrate properties (Invited Paper) [6474-13] S. Lautenschläger, C. Neumann, S. Graubner, J. Sann, F. Eylert, N. Volbers, B. K. Meyer, Justus Liebig Univ. Giessen (Germany); J. Bläsing, A. Krost, F. Bertram, J. Christen, Otto-vonGuericke-Univ. Magdeburg (Germany)

$64740 \mathrm{P}$-type nitrogen- and phosphorus-doped $\mathrm{ZnO}$ thin films grown by pulsed laser deposition on sapphire substrates (Invited Paper) [6474-14]

J.-P. Mosnier, S. Chakrabarti, B. Doggett, E. McGlynn, M. O. Henry, A. Meaney, Dublin City Univ. (Ireland)

64740J Formation of two-dimensional electron gas and enhancement of electron mobility by $\mathrm{Zn}$ polar ZnMgO/ZnO heterostructures (Invited Paper) [6474-15]

H. Tampo, H. Shibata, K. Matsubara, A. Yamada, P. Fons, National Institute of Advanced Industrial Science and Technology (Japan); M. Yamagata, H. Kanie, Tokyo Univ. of Science (Japan); S. Niki, National Institute of Advanced Industrial Science and Technology (Japan)

647400 Advances in nonpolar ZnO homoepitaxy: 1D surface nanostructure and electron transport (Invited Paper) [6474-18]

H. Matsui, H. Tabata, Osaka Univ. (Japan)

\section{SESSION $5 \quad$ ZnO PROCESSING AND CONTACT PREPARATION}

64740P Inductively coupled plasma etching of ZnO (Invited Paper) [6474-19]

K. J. Nordheden, Univ. of Kansas (USA); M. Dineen, C. Welch, Oxford Instruments Plasma Technology (United Kingdom)

$64740 Q \quad$ Etching of ZnO toward the development of ZnO homostructure LEDs (Invited Paper) [6474-20]

K. Minder, Northwestern Univ. (USA); F. H. Teherani, Nanovation SARL (France); D. Rogers, Nanovation SARL (France) and Univ. de Technologie de Troyes (France); C. Bayram,

R. McClintock, P. Kung, M. Razeghi, Northwestern Univ. (USA)

\section{SESSION 6 ZnO BASED DIODES AND LEDS}

64740V Surface plasmon mediated emission from metal/ZnO: an example for the fabrication of high brightness top-emitting light emitting diodes (Invited Paper) [6474-25]

H. C. Ong, D. Y. Lei, J. Li, The Chinese Univ. of Hong Kong (Hong Kong China) 
64740X Photonic properties of ZnO epilayers (Invited Paper) [6474-27]

M. R. Wagner, U. Haboeck, P. Zimmer, A. Hoffmann, Technische Univ. Berlin (Germany);

S. Lautenschläger, C. Neumann, J. Sann, B. K. Meyer, Justus Liebig Univ. Giessen (Germany)

647410 Studies of interfacial optical and electrical properties on dielectric/ZnO systems [6474-65]

R. S. Wang, H. C. Ong, The Chinese Univ. of Hong Kong (Hong Kong China)

\section{SESSION 8 ZnO BULK AND PHOTONIC CRYSTALS}

647412 State-of-the-art ZnO bulk crystal growth (Invited Paper) [6474-31]

T. Fukuda, Tohoku Univ. (Japan) and Fukuda Crystal Lab. (Japan); Y. Mikawa, Fukuda

Crystal Lab. (Japan); D. Ehrentraut, Tohoku Univ. (Japan)

647413 Vacancy defect distributions in bulk ZnO crystals (Invited Paper) [6474-32]

F. Tuomisto, Helsinki Univ. of Technology (Finland); D. C. Look, Wright State Univ. (USA) and

Air Force Research Lab. (USA)

\section{SESSION 9 ZnO BASED THIN FILM DEVICES}

647415 Surface acoustic wave devices (Invited Paper) [6474-34]

C. Müller, A. Nateprov, G. Obermeier, M. Klemm, V. Tsurkan, A. Wixforth, R. Tidecks, S. Horn, Univ. Augsburg (Germany)

647417 Growth and characterization of doped ZnO films (Invited Paper) [6474-36]

A. K. Pradhan, H. Mustafa, L. Douglas, R. Mundle, D. Hunter, K. Lord, T. Williams, R. Konda, O. Bamiduro, E. Annih, C. E. Bonner, Norfolk State Univ. (USA); I. V. Kityk, J. Dlugosz Univ. (Poland)

647418 Ga:ZnO based transparent conducting oxides and devices (Invited Paper) [6474-37]

V. Bhosle, J. Narayan, North Carolina State Univ. (USA)

647419 Scaling and parasitic effects in ZnO transparent thin film transistors (Invited Paper) [6474-38] C.-C. Wu, H.-H. Hsieh, National Taiwan Univ. (Taiwan)

$64741 \mathrm{~A}$ The characteristics of transparent metal-ZnO contacts and ZnO-based photodiodes (Invited Paper) [6474-39]

Y. Z. Chiou, Southern Taiwan Univ. (Taiwan); T. K. Lin, C. Y. Lu, S. P. Chang, National Cheng Kung Univ. (Taiwan); C. K. Wang, Epitech Technology Corp. (Taiwan); C. F. Kuo,

H. M. Chang, National Cheng Kung Univ. (Taiwan)

64741B Influence of annealing in oxygen ambient on crystal properties of rf-sputtered PZT layers on ZnO substrates [6474-63]

Ya. I. Alivov, F. Agra, B. Xiao, S. Chevtchenko, Virginia Commonwealth Univ. (USA);

C. Litton, Air Force Research Lab. (USA); H. Morkoç, Virginia Commonwealth Univ. (USA) 
64741E Metal oxide nanowires for optical gas sensing (Invited Paper) [6474-42]

C. Baratto, S. Bianchi, E. Comini, G. Faglia, M. Ferroni, G. Sberveglieri, CNR-INFM and Univ. of Brescia (Italy)

$64741 \mathrm{G}$ Enhancement of gas response of ZnO micro-nano structured films through plasma treatment [6474-56]

J.-J. Delaunay, K. Yanagisawa, T. Nishino, I. Yamada, The Univ. of Tokyo (Japan)

$64741 \mathrm{H}$ Fabrication and characterization of zinc oxide based rib waveguide [6474-60]

M. Gioffrè, Istituto per la Microelettronica e Microsistemi, CNR (Italy); M. Gagliardi,

M. Casalino, Univ. Mediterranea di Reggio Calabria (Italy); G. Coppola, M. Iodice, Istituto per la Microelettronica e Microsistemi, CNR (Italy); F. Della Corte, Univ. Mediterranea di Reggio Calabria (Italy)

\section{SESSION 11 ZnO BASED NANOSTRUCTURES II}

647411 Morphological control of ZnO nanostructures grown on silicon [6474-44]

R. T. Rajendra Kumar, J. Grabowska, J. P. Mosnier, M. O. Henry, E. McGlynn, Dublin City Univ. (Ireland)

$64741 \mathrm{~K}$ Optical characteristics of ZnO nanowires synthesized by nanoparticle-assisted deposition and their application to sensors (Invited Paper) [6474-46]

T. Okada, M. Ueda, J. Nishimura, J. Guo, M. Higashihata, J. Suehiro, Kyushu Univ. (Japan)

64741L Patterned growth of ZnO nanorod by solution chemical method [6474-47]

S.-H. Yi, S.-K. Choi, J.-M. Jang, S.-H. Ko, J.-A. Kim, W.-G. Jung, Kookmin Univ. (South Korea)

$64741 \mathrm{M}$ Carrier relaxation and stimulated emission in ZnO nanorods grown by catalyst-assisted vapor transport on various substrates [6474-48]

V. Avrutin, Ü. Özgür, N. Izyumskaya, S. Chevtchenko, J. Leach, J. C. Moore, A. A. Baski, Virginia Commonwealth Univ. (USA); C. Litton, Air Force Research Lab. (USA); H. O. Everitt, Duke Univ. (USA) and Army Aviation and Missile RDEC (USA); K. T. Tsen, Arizona State Univ. (USA); M. Abouzaid, P. Ruterana, SIFCOM, CNRS, ENSICAEN (France); H. Morkoç, Virginia Commonwealth Univ. (USA)

$64741 \mathrm{~N}$ Fabrication of well-aligned ZnO nanorods by hydrothermal process using GaN epitaxial layer [6474-57]

J.-M. Jang, S.-H. Yi, S.-K. Choi, J.-A. Kim, W.-G. Jung, Kookmin Univ. (South Korea)

\section{SESSION 12 SPINTRONICS AND FERROELECTRICS}

64741Q Transition-metal- and rare-earth-doped ZnO: a comparison of optical, magnetic, and structural behavior of bulk and thin films (Invited Paper) [6474-51]

W. E. Fenwick, M. H. Kane, Georgia Institute of Technology (USA); R. Varatharajan, Cermet, Inc. (USA); T. Zaidi, Z. Fang, Georgia Institute of Technology (USA); B. Nemeth, Cermet, Inc. (USA); D. J. Keeble, Univ. of Dundee (United Kingdom); H. El-Mkami, G. M. Smith, Univ. of St. Andrews (United Kingdom); J. Nause, Cermet, Inc. (USA); C. J. Summers, I. T. Ferguson,

Georgia Institute of Technology (USA) 
$64741 \mathrm{R}$ Transport properties of non magnetic and magnetic $\mathrm{ZnO}$ thin films under field effect (Invited Paper) [6474-52]

E. Bellingeri, I. Pallecchi, CNR-INFM LAMIA (Italy); M. Putti, L. Pellegrino, CNR-INFM LAMIA (Italy) and Genoa Univ. (Italy); A. Caviglia, G. Canu, Genoa Univ. (Italy); A. Gerbi, M. Vignolo, CNR-INFM LAMIA (Italy); A. S. Siri, D. Marré, CNR-INFM LAMIA (Italy) and Genoa Univ. (Italy)

$64741 \mathrm{~S}$ Polarization coupling in epitaxial $\mathrm{ZnO} / \mathrm{BaTiO}_{3}$ thin film heterostructures on $\mathrm{SrTiO}_{3}(100)$ substrates [6474-53]

M. Lorenz, M. Brandt, Univ. Leipzig (Germany); J. Schubert, Forschungszentrum Jülich GmbH (Germany); H. Hochmuth, H. von Wenckstern, Univ. Leipzig (Germany); M. Schubert, Univ. of Nebraska, Lincoln (USA); M. Grundmann, Univ. Leipzig (Germany)

Author Index 
Downloaded From: https://www.spiedigitallibrary.org/conference-proceedings-of-spie on 25 Apr 2023

Terms of Use: https://www.spiedigitallibrary.org/terms-of-use 


\title{
Conference Committee
}

\author{
Symposium Chair \\ Yakov Sidorin, Photineer Technology Group (USA) \\ Symposium Cochair
}

Ali Adibi, Georgia Institute of Technology (USA)

Program Track Chair

James G. Grote, Air Force Research Laboratory (USA)

Conference Chairs

Ferechteh Hosseini Teherani, Nanovation SARL (France)

Cole W. Litton, Air Force Research Laboratory (USA)

Program Committee

Jean-Jacques Delaunay, The University of Tokyo (Japan)

David C. Look, Wright State University (USA)

Tatsuo Okada, Kyushu University (Japan)

Seong-Ju Park, Gwangju Institute of Science and Technology (South Korea)

Manijeh Razeghi, Northwestern University (USA)

David Rogers, Nanovation SARL (France) and Universitè de Technologie de Troyes (France)

Jin-Joo Song, University of California, San Diego (USA)

Session Chairs

1 Optical Properties

Takafumi Yao, Tohoku University (Japan)

Alois Krost, Otto-von-Guericke-Universität Magdeburg (Germany)

$2 \quad$ ZnO Doping

Cole W. Litton, Air Force Research Laboratory (USA)

Axel Hoffmann, Technische Universität Berlin (Germany)

3 Thin Film Epitaxy and Interfaces

Jurgen Christen, Otto-von-Guericke-Universität Magdeburg (Germany)

Bruno K. Meyer, Justus-Liebig-Universität Giessen (Germany) 
Thin Film Heterostructures

David C. Look, Wright State University (USA)

Ferechteh Hosseini Teherani, Nanovation SARL (France)

$5 \quad$ ZnO Processing and Contact Preparation

Karen J. Nordheden, The University of Kansas (USA)

Enda McGlynn, Dublin City University (Ireland)

$6 \quad$ ZnO Based Diodes and LEDs

David Rogers, Nanovation SARL (France) and Universitè de Technologie de Troyes (France)

Seong-Ju Park, Gwangju Institute of Science and Technology (South Korea)

$7 \quad$ ZnO Materials and Properties

Olivier Durand, Thales Research \& Technology (France)

Ferechteh Hosseini Teherani, Nanovation SARL (France)

$8 \quad$ ZnO Bulk and Photonic Crystals

David C. Look, Wright State University (USA)

Karen J. Nordheden, The University of Kansas (USA)

$9 \quad$ ZnO Based Thin Film Devices

Leonard J. Brillson, The Ohio State University (USA)

Hitoshi Tampo, National Institute of Advanced Industrial Science and Technology (Japan)

10 ZnO Based Nanostructures I

Yicheng Lu, Rutgers University (USA)

Camilla Baratto, CNR-IFNM, Università degli Studi di Brescia (Italy)

11 ZnO Based Nanostructures II

Zhong Lin Wang, Georgia Institute of Technology (USA)

Kathryn A. Minder, Northwestern University (USA)

12 Spintronics and Ferroelectrics

Scott A. Chambers, Pacific Northwest National Laboratory (USA)

Jeff Nause, Cermet, Inc. (USA) 